\title{
From Arkngthand to Wretched Squalor: Fictional place-names in The Elder Scrolls universe
}

\author{
Tamás Fekete, University of Pécs (Hungary) and Ádám Porkoláb, \\ Independent linguist
}

\begin{abstract}
In this article we would like to examine an area of onomastics that has not received much scholarly attention. We aim to provide an adequate linguistic analysis of the place-names found in The Elder Scrolls (ES) video game series. For our analysis, we rely chiefly on the methods of linguistic statistics, which have not yet gained widespread use in onomastic research. Our goal is to give a boost to linguistic and onomastic research into video games and to develop related aspects of its research methodology. Two main methods of place-name formation can be observed in our results: one is when the fictional names are coined on the basis of the lexical elements of already existing non-fictional languages (we call these mimetic names), and the other is when the game developers create so-called speaking names. In our article we demonstrate that the toponyms of the ES universe in part conform to the conventions of non-fictional place-name formation (e.g. they can be sorted into the two main categories of habitative names and topographical names), and in part they contradict such conventions, because around 14 per cent of the names we analyzed are purposefully coined as semantically obscure toponyms, which does not happen in the case of non-fictional names.
\end{abstract}

\section{Introduction}

The recognition that playing is much more important in the emergence, preservation and propagation of culture than it had been thought before came in 1938, when Huizinga's (1980: 4) seminal work about the cultural history of play was published. As Huizinga writes: "In culture we find play as a given magnitude existing before culture itself existed, accompanying it and pervading it from the earliest beginnings right up to the phase of civilization we are now living in". 
Today the phrase homo ludens, 'playing man' that he coined, is part of scientific nomenclature. According to the Dutch cultural theorist, apart from providing a means of subsistence, play serves as the cradle of culture (Huizinga 1980: 29). Nearly a century later, Huizinga's original idea of the homo ludens is manifested in the online world of video games.

In recent years scientific research of video games has become a popular topic in scholarly articles on pedagogy, sociology and linguistics. The scientific discipline dealing with games is called 'ludology' (Frasca 2007: 86-87). According to Frasca, ludology is the name of the scientific field that analyzes games in general, which also includes video games (Frasca 2001, 2003: 222, 2007: 86-87). The term was originally used in connection with board games; thus we first encounter the notion of ludology outside the realm of electronic games. As Frasca (2001) points out, before the new millennium no coherent and formal scientific discipline existed for the study of games; therefore researchers turned to the tools of literary and film studies as well as narratology for their analysis (Frasca 2001).

However, works on games are not written just for the sake of writing about games. Similarly to the situation in Huizinga's time, games nowadays reflect aspects of culture and modern society. In the foreword to their analysis of digital fiction Bell, Ensslin and Rustad (2014: 3) emphasize that scholarly works about digital fiction "and their authors say something important about literature as an art form, about the media ecology of our time, and about our society and cultural practices". Despite all this, the scientific study of video games can still not be considered to be widely accepted. Bogost (2007: vii) believes that the reason for this is largely that video games are still seen as a medium for children, and thus playing video games is a useless waste of time for adults. Bogost suggests the second reason why such games are neglected to be their triviality (Bogost 2007: viii). The majority of society attaches little value to video games and considers them to be "weightless" as they are not integrated well enough into the common consciousness of society (Bogost 2007: viii). In our present article - in accordance with Huizinga's stance and the idea of games being important for culture - we accept the validity of analyzing video games from a scientific and more precisely linguistic point of view.

Let us now examine what sort of research methodology could be used for the analysis of video games. In her article, Ensslin (2015) describes many different types of discourse about video games: narratives, ludolect (i.e. metaludic communication), textuality, multimodal design and interaction. The caveat of Ensslin's list is that it omits the linguistic analysis of the game's fictional environment itself (e.g. the analysis of toponyms in the game), and considers only 
sociolinguistic and pragmatic analyses. Furthermore, in our opinion, her focus is overly narrow in terms of defining the framework of ludolects, because she focuses mainly on the communication between gamers and on the gamers' interaction with the game.

Another questionable aspect of this list is that it is not concerned with pedagogical discourse, more precisely the discussion of gamification. According to one of gamification's most prominent researchers, Jane McGonigal, video games are useful exactly because gamers are fed up with reality, and the virtual activities can help them cope with many problems and issues affecting them in their real lives by implicitly helping the gamers develop their problem-solving skills (McGonigal 2011). This positive activity that the gaming experience provides can easily be channelled into education: besides developing the various skills of students, their social competence and self-knowledge can also be improved by utilizing gamification (McGonigal 2011). Fromann considers gamification to be an optimal teaching method, whereby students experience classwork as a game and see problems as challenges (Fromann 2012, 2014, 2017; Fejes, Bajor and Fromann 2014; Damsa and Fromann 2016).

Barseghyan (2017) claims that video games - similarly to what has been discussed above - can make foreign language learning significantly easier for students. As an example, he cites Ubisoft's well-known game Assassin's Creed Unity. Barseghyan's analysis (2017: 16) reveals that by paying attention to the dialogues heard in the game, the students can familiarize themselves with, for instance, phrasal verbs, modal auxiliaries, and "colloquial language, clichés, pejorative (derogatory) words, vulgarisms, and swear words".

Our paper is concerned with Ensslin's category of metaludic communication, even though according to her own definition (Ensslin 2015: 5) ("linguistic interaction about games and gameplay, carried out by players as well as other participants in game culture") our research would not fit this category. However, it is our firm conviction that metaludic communication should not be restricted to the users' discourse about games, but its focus should be widened to include discourses about the fictional worlds themselves that these games present. An excellent example of research into metaludic communication is another study by Ensslin (2011b) in which she analyzes aspects of food in two gendered video games (Quake 4 and Desperate Housewives) and one agendered game (The Sims 2). Her conclusion is that the first-person shooter (FPS) game (Quake 4) "displays the human body as processable, technologically modifiable matter for alien consumption and reincarnation" (Ensslin 2011b: 37).

Our investigation was carried out in a similar vein, however. Instead of a semantic-semiotic approach, we utilized the more traditional tools of place- 
name research. Before we discuss the results, we present a brief literature review on the subject of fictional names.

\subsection{The analysis of fictional names}

A special group of place-names, and proper names in general, is that of names which did not emerge organically as a result of name-giving necessitated and motivated by socio-cultural factors, but are the results of deliberate, conscious naming by authors of fictional works of any genre. Studies of fictional names in the onomastic literature, with few exceptions (e.g. Butler 2015 about the names of video games in The Simpsons), are primarily concerned with the analysis of literary names. Investigations into video games from an onomastic perspective seem to be very marginal.

Non-fictional English toponyms, similarly to other Germanic place-names, can be of two major morphological types: 'simplex' and 'complex', depending on the number of elements they contain. Simplex names consist of only one element which can appear in its dictionary form, or carry inflectional or derivational affixes (e.g. Hastings 'settlement of the followers of a man called *Hoesta' (Mills 2011: 228)), while complex names are compounds which comprise two distinct elements: a specific and a generic. The former component is the first element of the name and it can either be a noun, or it can refer to the owner of the place (if the specific is a personal name) or it can denote some geographical, agricultural, religious or sociological characteristic feature of the locality (in case it is an adjective). A generic is usually the second element in a toponym and it defines the category to which the locality belongs (cf. Reaney 1985). Fekete provides the following definition of the second element:

The generic elements of place-names are always appellatives and their purpose is to classify, doing so by categorizing the locality in question as an outlying farmstead, a secondary settlement or a village, just to name the most frequently occurring ones [in the case of English toponyms].

(Fekete 2016: 10)

Furthermore, Cameron (1996: 25-26) identifies the following three types of English place-names as the most frequently occurring ones: habitative names (e.g. Higham 'high homestead'), topographical names (e.g. Blackburn 'dark stream') and tribal names (e.g. Ireby 'village of the Irish'). Toponyms belonging to the first category denote homesteads, houses, villages and generally any area that is inhabited by people. Topographical place-names describe topographical and natural features, while tribal names are created with reference to the tribes 
or other social groups inhabiting the area in which the toponym is found. In our observations, the ES database contains only habitative and topographical names, while tribal names are absent, which is in accordance with Cameron's observations that the overwhelming majority of English toponyms fall into these two categories.

As opposed to this, the characteristics of fictional names are slightly different, as it will be revealed in our analysis. Adams, Fuller and Stecker (1997) provide one of the most insightful descriptions of the semantics of fictional names. They claim that fictional names found in literary works and those found in discourse about literary figures are equally empty semantically (Adams, Fuller and Stecker 1997: 129; see also Braun 2005 for the discussion of similar issues).

The common consensus of the scholarly literature on the nature of fictional names seems to be that these names lack a real-world referent, and are thus merely empty labels. The majority of researchers discussing this topic approach it almost exclusively from the perspective of semantics and/or formal logic and from a solely theoretical angle, focusing on issues regarding the truth values and truth conditions of sentences that feature fictional names (see e.g. Carney 1977; Currie 1988; Adams, Fuller and Stecker 1997; Braun 2005; Tiedke 2011; de Ponte, Korta and Perry 2018).

Contrary to this tradition, our article is not aimed at the semantic or pragmatic analysis of fictional names, our goal is rather to discuss and analyze the morphological and onomastic aspects of fictional toponyms. Still, however, we do deal with the variable of semantic transparency, but only as one of a number of characteristic features of the names at hand, rather than as a feature to be discussed in terms of semantic theory.

It is also our stance that contrary to popular belief, the notion of fictional place-names needs to be revised in order to be analyzable, because basically fictional toponyms or other fictional proper names can, in fact, have reference ${ }^{1}$ much the same way as a non-fictional name can. A workaround for this issue is provided by Friedhelm Debus (2002). Debus proposes that, besides the semantic aspects of fictional toponyms, their analysis should take into consideration their categorical-semantic aspects as well (Debus 2002: 32). Essentially, these are pieces of information which cannot easily be quantified such as the social status of the person who bears the name, or references to location or age. According to Debus (2002: 32), these categories form a transition towards the name's connotations.

The categorical-semantic aspects of fictional names proposed by Debus can convey a lot of information. An excellent example for the analysis of such pieces of information is the study by Csóti and Szabó (2016), in which the 
authors examine the original English personal names found in the Harry Potter universe along with their Hungarian translations. Csóti and Szabó (2016) identify 4 main methods of coining personal names: (i) deliberate coinages (within this category they separate intertextually motivated names, the use of mythological names, and humorous names), (ii) names referring to the individual's origin, (iii) names referring to the individual's occupation, and (iv) names reflecting internal or external features and traits of the individual (Csóti and Szabó 2016).

Concerning the analysis of place-names in general (whether real or fictional), it can be stated that every name-giving act is a semantically conscious and deliberate one, and at least to some extent every name is semantically motivated (Ditrói 2017: 24-25). Therefore, place-name formation cannot be considered a random, haphazard phenomenon, because all proper nouns ultimately originate as semantically transparent, meaningful lexical items, adequately descriptive of whatever they denote, therefore the same phonological, morphological, word formational and syntactic rules and constraints apply to them as to the whole of the language and to the formation of words belonging to other word classes (Nicolaisen 1976: 151; see Clark 1992: 452; Gammeltoft 2007: 481).

However, fictional place-names constitute a somewhat distinct category. They are distinct because they are not the result of an organic development initiated and accepted conventionally by a speech community, but the result of the conscious decision of one or more individuals who coined the names. The other distinction is that unlike real-world toponyms, fictional ones can begin their life as already darkened (semantically) while, as stated above, real place-names are always transparent initially if coined by the speech community of the language in which the toponym appears. As we will show later on, this feature of fictional place-names is especially important in our analysis and in the way in which these names are used in the fictional world of the video game.

As we have already mentioned above, the bulk of scholarly literature available on the topic of video game onomastics is concerned with the online identities and name-giving patterns of the players. In our opinion, the analysis of online virtual identities belongs more to the intersection between the realms of literary studies, or more precisely narratology, and linguistics. A central question of many scholarly works written on the subject is how the virtual self represents the player's real consciousness in a digital environment (see e.g. Ensslin 2011a, 2011c; Kline 2014). Given that physical embodiment is impossible in a virtual world made up of ones and zeroes, language and verbal expression naturally become the cornerstones of online identity. Thus, the focus of researchers on digital naming is understandable because in the online world the name of the character that represents the player's consciousness provides the framework for 
their identity, which cannot be alienated and detached from the real-world experiences and personality of the player. A similar issue is investigated by Kelley (2012), who looked into the correlation between the online names and sexual identities of homosexual players. According to his conclusions, "gay naming in online gaming may not be all that different from gay naming in the so-called real world, where one finds a similar tendency for organizational names to conceal nearly as much as they reveal" (Kelley 2012: 199). This metanarrative speech act of naming that reflects the real world shows parallels with the place-names found in the game we analyzed.

In the Hungarian context, Kepes (2009) investigated the patterns of online character names through the analysis of 1600 online names and a six-item questionnaire and attempted to distil the characteristics of these names via semantic and cognitive semantic analyses. The questionnaire contained questions pertaining to the informants' age and gender, their character's name, race and caste, the motivation behind the name-giving act, what they consider to be a good name and how important name-giving is in the case of the players' own character and in the case of other players' characters. According to her results (398 answers), the naming habits of World of Warcraft players differ from conventional norms because they follow "the naming conventions of the culture and history of the game's universe"2 (Kepes 2009: 67). The analysis of naming patterns in the online role-playing game $A I O N$ (Somogyi 2015) yielded similar results: players consider in-game naming to be as important as naming a newborn child, but their choice is significantly influenced by community norms, and a very important criterion is that the name should pique the interest of other players (Somogyi 2015: 36).

In linguistics, this type of name-giving is called postmodern naming, which means the purposeful absence of implicit or explicit category marking and builds heavily on the associative links stemming from and resonating with the players' knowledge.

Tolcsvai Nagy (1996) summarizes the characteristics of such names: "Postmodern naming deliberately plays on dissemination and the spoken and intimate linguistic registers, thus its interpretations are open and available for connotative meanings to emerge, which makes denotation problematic." (Tolcsvai Nagy 1996: 323)

Although Tolcsvai's analysis was based on band names and club names of English origin that had an ephemeral effect on Hungarian names, from the results of Kepes (2009) and Somogyi (2015) it seems obvious that Tolcsvai's ideas can be transferred to the analysis of fictional naming in video games. 
We consider the fictional names found in video games to be equivalent and parallel constructions to non-fictional place-names. We wish to analyze these onomastic items through statistics and other methods that are commonly utilized for investigating non-fictional toponyms. One of the aims of our article is to provide a general analytical framework and some methodological guidance for future research into the subject at hand.

Based on the experience with the analysis of Old Norse place-names, we treated the type of place-names, the number of elements the toponym comprises and the onomastic characteristics of the names (compound, multiword, transparency, etc.) as variables in our research. Upon further inspection of the scholarly literature, we also took into consideration whether or not the name was mimetic and if that were the case, which language was it trying to emulate. Similarly, we also determined for each name whether or not it is a 'speaking' name.

\subsection{Presuppositions, hypotheses}

Our research hypotheses were the following:

H1. Some parallels can be found between the fictional names of the ES series and non-fictional naming; therefore we cannot speak about "postmodern naming" in connection with the toponyms in the games (Tolcsvai Nagy 1996; Slíz 2006)

H2. Upon preliminary inspection of the games' onomasticon, we presuppose that the larger and more significant geographic units exhibit different naming patterns and methods than smaller, less significant ones do.

H3. Building on the players' linguistic competence is especially important for name-giving in the games, therefore semantic transparency is of utmost importance in the case of in-game toponyms.

\section{$2 \quad$ A brief history of The Elder Scrolls series ${ }^{3}$}

The ES series belongs to the genre of action role-playing video games (ARPG), which means that the player's goal, besides completing the main objectives of the game, is to develop their character through the completion of side quests and other challenges. The series is very elaborate in this respect because, according to Goh's estimation (2016: 2), in order to complete the latest ES title (Skyrim) around 300 hours of gameplay is needed. 
The game is chiefly single-player, perhaps because this way the gamer can experience what it is like to be the exiled, socially outcast main character. Bethesda Softworks commissioned ZeniMax Online Studios to develop an online edition of Elder Scrolls, the result of which was a massively multiplayer online role-playing video game (MMORPG), released in 2014.

The Elder Scrolls series was developed by Bethesda Softworks, and the first game, subtitled Arena, was released in 1994 for MS-DOS. The main novelty of the game series lied in the vast area the player can explore and the sandbox gameplay. As a result, the player was not bound by the linearity of the game's narrative, but could freely roam the virtual space of the game, which, according to the developers, has an area of eight million square kilometres. The player could freely explore settlements and interact with non-playable characters. Besides, players also had the possibility to develop their character's combat and magic skills (Beregi 2010: 362-363; Majewski 2017). In the second title of the series (Daggerfall, released in 1996), the developers added 15 thousand towns and 75 thousand non-player characters, but the grandiosity of the game is also reflected in the high number of bugs and errors, as certain side quests simply cannot be completed. This attention to detail was not only unique at the time of the title's release but still provides inspiration for modern games: the player can own ships and houses, can turn into a werewolf or a vampire and ride horses between locations. The night-day cycle and changes in the weather also add to the already quite elaborate game design (Beregi 2010: 362-363; Majewski 2017). ${ }^{4}$

One of the features of the series is that the play has the opportunity to join various factions, whereby they can freely utilize the resources offered by the faction during missions (plus, each guild provides the player with some extra reward). In order to join the faction, the player must complete a side quest related to the given faction. In the latest title of the series, Skyrim, the player can join at least 6 different factions: The Companion which is the guild of warriors; the rebellious Stormcloaks, The Imperials who are the guardians of the current order, The Thieves' Guild and the Dark Brotherhood which comprises assassins (Goh 2016: 2).

According to Majewski (2017: 52), the first two instalments of the series (Arena and Daggerfall) strongly resembles the classic pen-and-article RPGs "under the hood" (Majewski 2017: 52), which is reflected in the character classes and the fact that the game's rules are based on throwing dice. Radical changes were only introduced in the 2002 title, Morrowind, in which the whatyou-see-is-what-you-get (WYSIWYG) mechanics rises to prominence. In the fifth member of the series, Skyrim, which was released in 2011, the break from 
classic RPGs becomes evident. In this game, the developers removed static character classes and tried to "blend" players with their characters (Majewski 2017: 53).

The attention to detail seen in Daggerfall is also observable in the third title, Morrowind (released in 2002), which was followed by Oblivion in 2006 and finally Skyrim in 2011. As the games' popularity grew, the number of platforms for which the games became available also expanded. Skyrim, the fifth element of the series, is available for Windows, PlayStation 3 and 4, Xbox 360 and Xbox One, and it is also downloadable from the most popular digital distribution platform, Steam. By the end of 2017, Skyrim became available for Nintendo Switch and PlayStation VR.

During the 2018 Electronic Entertainment Expo (E3), Bethesda Softworks officially announced The Elders Scrolls 6, so the success story of the video game series will definitely continue (Makuch 2018).

The most important characteristic of the series has remained unchanged since the first title: the elaborate mythology, the free roam gameplay mode, and the numerous opportunities of interacting with non-player characters (Majewski 2017).

\section{Research methodology}

\subsection{Introductory remarks}

We utilized standard quantitative research methods for our analysis that we carried out on a database of fictional place-names pertaining to The Elder Scrolls video game series obtained from The Elder Scrolls Wiki website. The sample contained 1042 toponyms, and during the compilation of the database, our intention was to represent every place-name of the game's universe. Data collection was carried out between 1 June 2018, and 5 June 2018.

The aim of our research was to explore the patterns and methods of placename formation in the above-mentioned video game series and to draw general conclusions regarding the creation of fictional toponyms in video games. We also relied on Carrillo Masso's (2009) work on mixed research methodology. Given that we utilized both qualitative and quantitative methods, our research study is a mixed-based one. We attempted to triangulate the data by drawing database entries from 6 games. Given that we did not rely on linguistic data from actual speakers, we could not utilize the classic questionnaire method.

Quantitative research methodology aims to draw generalizable conclusions on the basis of extensive databases whose analysis can easily be automated. The 
main goal of quantitative research is to achieve representativeness, which means that the conclusions should be applicable to the entire population.

Such a goal can be best achieved via mathematical and statistical analyses, which yield objective results, which can be interpreted by deductive reasoning. A quantitative approach is rigorous and takes only a select number of variables into consideration, and the sample size cannot be extended once the analysis has begun. Therefore, quantitative research can be considered static and structured, as it establishes a sphere of observed variables and variables that are irrelevant for the research. This type of research focuses on hypotheses, thus being able to confirm or reject them is of utmost importance. This methodology promotes objectivity and the non-involvement of the researcher in data elicitation. Quantitative data analysis strives to uncover generalizable patterns and rules. As a result, this method is not adequate for analyzing individual cases.

With a quantitative approach, we can objectively describe our sample, and the most important task of quantitative analysis is to test hypotheses in order to confirm or reject the researcher's ideas. The evaluation of quantitative data hinges on validity, reliability, objectivity and generalizability. (The discussion of quantitative methodology here was based on Bryman 2006; Dörnyei 2007: 3234; Juhász 2007: 82).

\subsection{The structure of the database and methods of data analysis}

Our database comprises 1042 place-names from 6 games in The Elders Scrolls universe (Elders Scrolls 1-5. and The Elder Scrolls Online) that were drawn from The Elders Wiki, ${ }^{5}$ edited by the players. The toponyms were collected manually from the above mentioned Wiki site and stored and coded on an Excel 2016 spreadsheet. Although we strove to be as inclusive as possible, the database cannot be considered to be complete and to contain all the place-names of this fictional universe. The collected data were subjected to statistical procedures.

When establishing the categories we drew partly on the experience and methodology employed for the compilation of a database of English placenames (Fekete 2017), and we also found it adequate to analyze our data by means of linguistic statistics (Porkoláb 2017).

We aimed to provide a deep and detailed analysis of the onymic landscape (Dalen-Oskam 2016). Given that the narrative universe of The Elder Scrolls is very extensive, we restricted our focus solely on place-names, however. We do acknowledge that it would be highly beneficial to bring under scrutiny every personal and place-name of the extended ES universe. 
The most important characteristics of the research variables are summarized in Table 1. It is important to note that these categories are not mutually exclusive, because, for instance, a place-name containing a compound word can easily belong at the same time to the group of toponyms that have semantically opaque elements.

Table 1: Characteristics of the variables included in the study

\begin{tabular}{|c|c|c|c|}
\hline $\begin{array}{l}\text { Name of } \\
\text { variable }\end{array}$ & Aim of analysis & $\begin{array}{l}\text { Type of } \\
\text { variable }\end{array}$ & $\begin{array}{l}\text { Abbreviation } \\
\text { (used in SPSS) }\end{array}$ \\
\hline Name & Identification of names & nominal & name \\
\hline Type & $\begin{array}{l}\text { Which of the } 50 \text { types does the name belong } \\
\text { to? }\end{array}$ & nominal & type \\
\hline $\begin{array}{l}\text { Total number } \\
\text { of elements }\end{array}$ & $\begin{array}{l}\text { How many elements does the name } \\
\text { comprise? }\end{array}$ & scalar & element_number \\
\hline Compound & Does the name contain a compound word? & $\begin{array}{l}\text { nominal/ } \\
\text { dichotomous }\end{array}$ & compound \\
\hline Multi-word & $\begin{array}{l}\text { Is the name made up of several separate } \\
\text { elements? }\end{array}$ & $\begin{array}{l}\text { nominal/ } \\
\text { dichotomous }\end{array}$ & multiword \\
\hline Mimetic & Is the name mimetic? & $\begin{array}{l}\text { nominal/ } \\
\text { dichotomous }\end{array}$ & mimetic \\
\hline Mimetic type & Which language is the name imitating? & nominal & mim_type \\
\hline Speaking name & Is the toponym a speaking name? & $\begin{array}{l}\text { nominal/ } \\
\text { dichotomous }\end{array}$ & speakname \\
\hline $\begin{array}{l}\text { Transparent } \\
\text { names }\end{array}$ & $\begin{array}{l}\text { Does the name contain at least one } \\
\text { semantically transparent element? }\end{array}$ & $\begin{array}{l}\text { nominal/ } \\
\text { dichotomous }\end{array}$ & transparent \\
\hline Semi-transparent & $\begin{array}{l}\text { Does the name contain at least one partially } \\
\text { transparent element? }\end{array}$ & $\begin{array}{l}\text { nominal/ } \\
\text { dichotomous }\end{array}$ & semitrans \\
\hline Darkened & $\begin{array}{l}\text { Does the name contain at least one opaque } \\
\text { element? }\end{array}$ & $\begin{array}{l}\text { nominal/ } \\
\text { dichotomous }\end{array}$ & darkened \\
\hline Common nouns & Does the name contain common nouns? ${ }^{7}$ & $\begin{array}{l}\text { nominal/ } \\
\text { dichotomous }\end{array}$ & commonnoun \\
\hline
\end{tabular}

Based on a previous examination of English place-names (Fekete 2017), we established the following categories for our analysis: does the place-name contain one or more compound words, is the place-name made up of several noncompound words (we called this type 'multi-word' toponyms), is the placename mimetic (if yes, what language is it copying), and is the toponym a so- 
called 'speaking name'. Besides this, we also coded the semantic transparency of each place-name. A percentage of 75 per cent of our variables ( 9 out of a total of 12) is dichotomous, which means that they can only take two values (e.g. 'yes' or 'no', 'true' or 'false', 'male' or 'female'). Furthermore, these variables are of a nominal type; therefore their values are not quantifiable and cannot be meaningfully ranked or measured. Our non-dichotomous variables were the type of place-name, the type of mimesis, and the number of elements making up the toponym. A classic grouping variable would be the type of place-names.

We stored the data in Excel 2016 and analyzed it in IBM SPSS Statistics, version 20 , which is considered one of the standard pieces of software for running statistical tests.

In accordance with standard procedure, the data was first tested for distributional normality (Székhelyi and Barna 2003; Sajtos and Mitev 2007; Huzsvai and Vincze 2012). To determine whether our data is in fact normally distributed we ran the Kolmogorov-Smirnov test and the Shapiro-Wilk test in SPSS. In essence, normal distribution means that the 95 per cent of the values fall within two standard deviations from the mean. Large-scale samples with data collected via validated instruments created and tested by entire research groups are likely to yield normally distributed values. However, given that in this article we worked overwhelmingly with dichotomous variables (see Table 1), we cannot talk about any kind of normality of distribution in their case, since it is impossible for two values to be positioned on a bell curve. Thus, the notion of normality is not applicable to these variables, and the tests of normality can only yield relevant results for the variable of element number, as it is a numeric (scalar) variable.

Both the Kolmogorov-Smirnov and the Shapiro-Wilk test returned results that indicate a non-normal distribution in the case of the element number variable ( $p<0.001$ for both tests). Our data would be considered to be normally distributed if the tests of normality returned a significance level of $p>0.05$. This means that neither the t-test nor the analysis of variance (ANOVA) can be calculated for our dataset, but we will have to use nonparametric tests instead. In practice, if only values pertaining to a variable are not normally distributed, parametric tests cannot be used on those values.

The most frequently used nonparametric tests (e.g. the Mann-Whitney Utest and the Kruskal-Wallis test) cannot be applied to dichotomous variables; therefore we used Pearson's chi-square $\left(\chi^{2}\right)$ test to analyze the correlation between them. The chi-square $\left(\chi^{2}\right)$ tests were run in SPSS, for which the variables in question were first cross-tabulated (Table 2 contains the summary of which variables were entered into the contingency tables). Besides the test sta- 
tistics and significance levels, we also calculated Cramér's V $\left(\varphi_{c}\right)$ and the phi coefficient $(\varphi)$ in each case. Both of these values indicate the strength of association between two variables as well as the nature of the association (positive or negative). In our analysis, all chi-square tests met the required assumption for the expected count in each cell. Unless otherwise stated, this assumption is valid for all the reported chi-square tests.

Table 2: Cross tabulated variables for the chi-square $\left(\chi^{2}\right)$ tests

\begin{tabular}{|l|l|l|l|l|l|l|l|c|}
\hline & compound & speakname & mimetic & $\begin{array}{l}\text { trans- } \\
\text { parent }\end{array}$ & $\begin{array}{l}\text { multi- } \\
\text { word }\end{array}$ & $\begin{array}{l}\text { semi- } \\
\text { trans }\end{array}$ & $\begin{array}{l}\text { dark- } \\
\text { ened }\end{array}$ & common \\
\hline compound & X & $\checkmark$ & $\checkmark$ & $\checkmark$ & $\checkmark$ & $\checkmark$ & $\checkmark$ & $\checkmark$ \\
\hline speakname & $\checkmark$ & $\mathrm{X}$ & $\checkmark$ & $\checkmark$ & $\checkmark$ & $\checkmark$ & $\checkmark$ & $\checkmark$ \\
\hline mimetic & $\checkmark$ & $\checkmark$ & $\mathrm{X}$ & $\checkmark$ & $\checkmark$ & $\checkmark$ & $\checkmark$ & $\checkmark$ \\
\hline
\end{tabular}

Besides running the chi-square $\left(\chi^{2}\right)$ test for our dichotomous variables, we analyzed the only scalar variable (number of elements) in our sample with the help of the nonparametric Mann-Whitney and Kruskal-Wallis tests. The former is the nonparametric equivalent of the t-test, while the mechanism of the latter corresponds to the parametric analysis of variance (ANOVA). The Mann-Whitney Utest measures the distribution of values between two groups, and if $p>0.05$ then the distribution is the same across the two groups, meaning that there is no significant difference, while if $p<0.05$ then the difference between the two groups is statistically significant. This test is only valid for non-nominal variables; therefore we applied it to the scalar variable of element number, and ran the test with the following grouping variables: ${ }^{7}$

- speakname

- transparent

- mimetic

- darkened

- semitrans 
The Kruskal-Wallis test is similar to the one we mentioned above, the only difference being that this test can be used for comparing the distribution of values if there are more than two groups to compare. We ran this test for the variable of element number too, with the following grouping variables:

- mim_type

- type

As an additional test we calculated the $\eta$ (eta) coefficient to determine the strength and type of correlation between the scalar variable and each of the dichotomous nominal variables, which returned figures indicating only very weak or nonexistent correlations in every case. However, the significance level was always $p<0.05$.

\section{Coding, categories, variables}

When establishing the coding categories for our data, we individually considered and categorized the 1042 place-names. The basis of taxonomization was the semantic and information content of the place-name, and in uncertain cases or in cases when the toponym did not contain any indication of its type we relied on the categorizations found on The Elder Scrolls Wiki.

Since the categorization system of our source (The Elder Scrolls Wiki) proved to be very elaborate and therefore difficult to code, we simplified its system to have only 50 different types of place-names. We had to reduce the number of categories to 50 for practical reasons, such as statistical analysis and the storyline of the games. ${ }^{8}$ If we had relied on a more elaborate system of categorization (leaving the original classifications of the Wiki site intact), then the statistical analysis would have been difficult to carry out, because this would have resulted in categories that have very few elements, thus becoming difficult to compare with statistical methods. As a result of this restructuring, we had to combine smaller, related subcategories and further broaden some higher-level ones. For instance, the category of 'POI (point of interest)' comprises the names of places that bear some significance for the narrative structure of the game, e.g. 'fishery', 'wetland', 'group boss location', and 'pass'. The category of 'farm' includes toponyms carrying the element plantation. Events and locations not pertaining to the original dimension or world of the game play a very important role. We grouped these together under the 'realms' label to which we also added toponyms in the category of 'afterlife'. Due to the fact that the definite article the carries no significant meaning in the place-names of the game and in our research, we did not include it in the 'element number' variable. 
We established the following types of place-names for our analysis:

$\begin{array}{ll}\text { arena } & \text { Ayleid ruin } \\ \text { camp/outpost } & \text { cave } \\ \text { cemetery } & \text { city } \\ \text { clearing } & \text { country name } \\ \text { crafting location } & \text { Daedric shrine } \\ \text { dark anchor } & \text { dock } \\ \text { dragon lair } & \text { dungeon } \\ \text { Dwarven ruin } & \text { farm } \\ \text { fort/stronghold } & \text { grove } \\ \text { headquarters } & \text { hold name (administrative) } \\ \text { house name/personal residence } & \text { imperial camp } \\ \text { imperial fort } & \text { inn and tavern } \\ \text { island } & \text { keep/tower } \\ \text { landmark } & \text { lighthouse } \\ \text { lumber mill } & \text { main quest location } \\ \text { major city } & \text { mine } \\ \text { mountain/hill } & \text { nordic tower } \\ \text { orc stronghold } & \text { POI } \\ \text { quest location } & \text { realms } \\ \text { ruins } & \text { shack } \\ \text { ship and shipwreck } & \text { shop/administrative building } \\ \text { stable } & \text { standing stone } \\ \text { stormcloak camp } & \text { temple } \\ \text { tomb } & \text { town/settlement/homestead } \\ \text { watchtower } & \text { wayshrine } \\ & \end{array}$

As the results of the Kruskal-Wallis test show, with the exception of two name types (city and major city) no other pairs of variables exhibited statistically significant differences in terms of element number. Of these two types, major city shows significant differences with 25 other types of place-names, while city shows statistically significant differences with 6 other types. 


\section{$5 \quad$ Results and discussion}

Before running the above mentioned statistical tests in SPSS, we produced a descriptive analysis of the variables and the database itself. From this it emerged that on average the place-names at hand consist of 2.39 elements, the median of the number of elements is 2 , while its standard deviation is $\sigma=0.704$. This low value of standard deviation shows that there is very little variance $\left(\sigma^{2}=0.495\right)$ in terms of how many elements make up these fictional toponyms, as the most frequently occurring type seems to comprise only two elements. This is in accordance with non-fictional English toponyms because their overwhelming majority also consists of only two elements.

In many cases the toponyms in our database can fall into more than one category, for instance, one and the same name can simultaneously belong to the group of speaking names, compound names, and transparent names (e.g. Bonechill Passage, Iron-Breaker Mine, Moorside Inn). Therefore, we omit the inclusion of data about how many place-names fall into each category, because we consider such pieces of information to be misleading due to the above-mentioned reason.

\subsection{Mimetic names}

Even in the early stages of our research, it was apparent that a distinct group of toponyms deliberately imitate the phonetic patterns of other languages. In such cases, we also included in our data the language that the names tried to imitate, if it was identifiable. In this article we consider any name to be a mimetic name if it was coined on the basis of analogy with the typical phonetic patterns of common lexical elements of non-fictional languages in such a way that the original semantic content of the imitated word still remains at least partially discernible or is able to evoke associations. We were able to distinguish 10 non-fictional languages or language families in the database, which we summarized in Table 3. The distribution of names among these 10 categories is illustrated by Diagram 1. In the diagram the actual number of tokens is given in brackets after the percentage. 
Table 3: Features of mimetic place-names $(\mathrm{N}=234)$

\begin{tabular}{|l|l|}
\hline $\begin{array}{l}\text { Imitated language or } \\
\text { language family }\end{array}$ & $\begin{array}{l}\text { Average number of } \\
\text { elements (count) }\end{array}$ \\
\hline Norse & 2.28 \\
\hline Latin & 1.95 \\
\hline Germanic & 2.38 \\
\hline Arabic & 2.26 \\
\hline Ancient Greek/Greek & 1.65 \\
\hline Slavic & 2.60 \\
\hline Celtic & 2.50 \\
\hline Hebrew & 2.25 \\
\hline French & 1.50 \\
\hline Old English & N/A \\
\hline
\end{tabular}

1. This category consists of only one name.

Our descriptive analysis revealed that 32.9 per cent of mimetic names contain a compound word, while 70.9 per cent of them consist of at least two separate elements. 12.4 per cent of mimetic names are speaking names, and only 3 per cent of mimetic names are semantically transparent. In this category, 63.2 per cent of names contain a partially transparent element and 33.8 per cent comprise a semantically opaque item. 13.2 per cent of names that belong in this category contain a common noun.

Among the categories listed in Table 3 we can find, among others, Latin, which was a high prestige language in the Middle Ages, French, which is the language of diplomacy, and Ancient Greek, which is the language of medicine. All of this seems to echo DiPietro's (2014) article about the medieval nature of the ES universe. Most of the languages used for coining mimetic names historically or genealogically can be strongly linked to English, e.g. French (e.g. Noellaume Estate), Norse (e.g. Hjaalmarch), Celtic (e.g. Glenmoril Coven), Old English (e.g. Kynesgrove), or Latin (e.g. Arx Corinium). The inclusion of nonEuropean languages (Arabic [e.g. Xal Haj-El Shrine] and Hebrew [e.g. Nchuand-Zel]) in mimetic names is probably a result of postmodern naming and its associative nature (most likely evoking the connotations of exoticism for English-speakers). It can also be observed that personal names that feature in 
place-names in the game can hint at the social rank of their bearer Viola Giordano's House would imply that the proprietor is of aristocratic origin, while Ysolda's House implies that it is owned by a commoner.

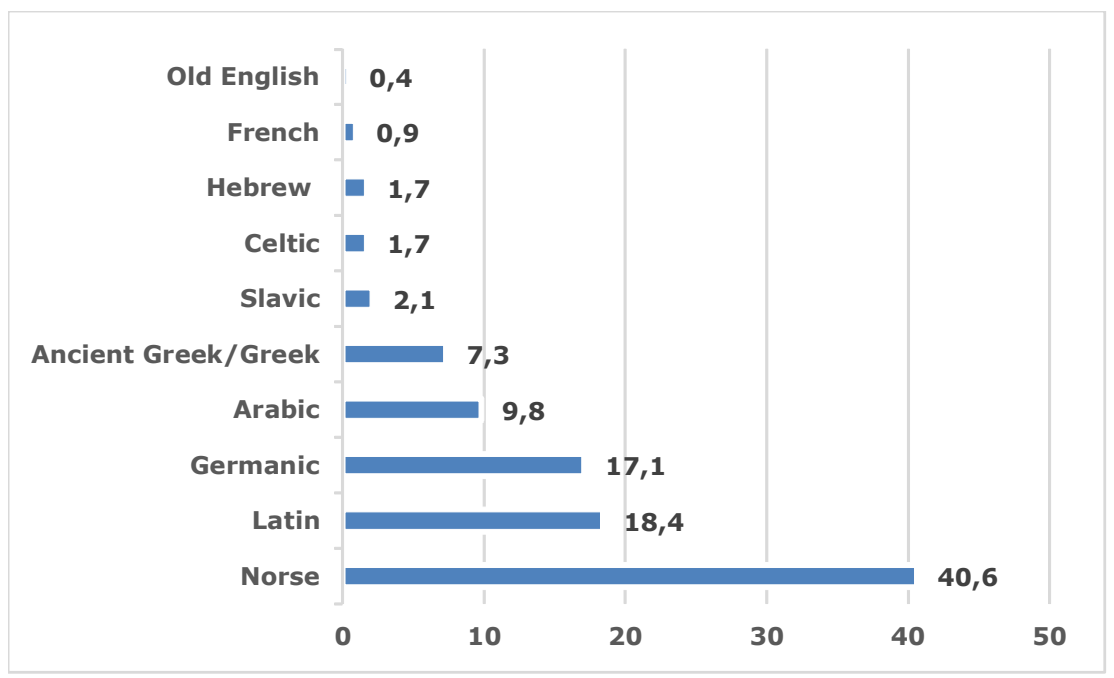

Diagram 1: The distribution of mimetic names across languages (percentages and raw count)

In this category, by far the highest percentage is that of names carrying forms that imitate Norse phonetic features (40.6 per cent of all mimetic names). Apart from names resembling Scandinavian lexical items, Germanic and Arabic sounding toponyms are also quite frequent.

We also observed that the various types of mimetic names can be separated geographically. For instance, place-names of the northern territories of the game show significant Norse influence, while toponyms in dry, desert regions exhibit a resemblance to Arabic names.

Given our lack of expertise in fictional languages, we did not set up separate categories for these in the ES universe, such as the fictional Dwarven or Elvish language. However, geographical and typological correlations could also exist, but due to a lack of reliable data, given that the ES Wiki site at the time of data collection did not include any relevant pieces of information about language families and geographical spread of languages, we cannot draw definite conclusions. 
Table 4: Results of the chi-square $\left(\chi^{2}\right)$ tests of mimetic names

\begin{tabular}{|l|l|l|l|l|l|}
\cline { 2 - 6 } \multicolumn{1}{c|}{} & \multicolumn{3}{c|}{ Pearson Chi-square } & \multicolumn{2}{c|}{ Symmetric measures } \\
\cline { 2 - 7 } \multicolumn{1}{c|}{} & value & df & sig & phi & sig \\
\hline Compound & 7.945 & 1 & 0.005 & -0.087 & 0.005 \\
\hline Multiword & 18.938 & 1 & 0.000 & -0.135 & 0.000 \\
\hline Speakname & 208.572 & 1 & 0.000 & -0.447 & 0.000 \\
\hline Transparent & 277.843 & 1 & 0.000 & -0.516 & 0.000 \\
\hline Semitrans & 103.057 & 1 & 0.000 & 0.314 & 0.000 \\
\hline Darkened & 100.755 & 1 & 0.000 & 0.311 & 0.000 \\
\hline Commonnouns & 252.578 & 1 & 0.000 & -0.492 & 0.000 \\
\hline
\end{tabular}

The $\chi^{2}$ test of the correlation between mimetic names and the other variables revealed (see Table 4 ) that this category shows a statically significant correlation with every other variable ( $p<0.05$ in each case). However, the $\varphi$ coefficient reveals that only in the cases of speaking names, transparent names, and names containing common nouns can we, in fact, observe adequate correlational strength. Still, this correlation is rather weak in every case. Therefore it cannot be taken to conclusively prove correlation. These results show that these variables are inversely proportionate, which means that the higher the value of speaking name, transparent name, and common noun name is, the lower the value of mimetic names is. This indicates that mimetic names tend to be less transparent and contain a lower number of common nouns. The category of mimetic names does not show any discernible correlational strength with the rest of the variables. Therefore it seems unlikely that there is any correlation between them.

We also carried out the Mann-Whitney U-test for our analysis for the variable of element number, which revealed that mimetic names consist of significantly fewer elements than non-mimetic names $(U=73954.5, p<0.001) .74$ per cent of mimetic names consist of one or two elements, while this is true about only 53.5 per cent of non-mimetic toponyms. In contrast, 26 per cent of mimetic names comprise three or more elements, while this ratio is 46.5 per cent in the case of non-mimetic place-names. One of the main features of mimetic names seems to be shortness because their purpose is solely to imitate the phonetic patterns of a given language, and not to carry lexical meaning or have categorical elements in them. 


\subsection{Speaking names}

We considered those place-names to be speaking names that "convey a distinguishable meaning, or consist of sound sequences evoking emotions or feelings, or are related to some notion, opinion or tradition" (Slíz 2006: 290). Speaking names differ from the above discussed mimetic names in that they do not evoke the associations by imitating foreign sound sequences but by utilizing the meanings of lexical elements present in the language in which the name was coined in order to reflect on some characteristic feature of the given locality.

Speaking names in fiction very often serve as vehicles of irony and satire, although they can also be used for non-fictional place-name formation (for instance a very infertile piece of land in the Hungarian village of Tar is called Bárnevóna which translates as 'if only it didn't exist' and lies not far away from the high quality soil of Úrráteszi-dülö 'will-make-you-rich hill' in Gyöngyöspata, Hungary). Speaking names from the game include Bleakrock Isle, Bonechill Passage, Deathclaw's Lair, Iron-Breaker Mine, Shimmermist Cave.

Speaking names are an integral part of establishing the game's mood and they may serve as indicators for the player concerning the tasks to be completed at a certain location (e.g. Selene's Web).

In the English language scholarly literature, the topic of speaking names is underrepresented; therefore we relied mostly on Hungarian sources in our analysis and discussion of such names. Concerning speaking names in fiction, the Hungarian sources focus on their ironical and satirical usage. Nilsen's work (1982) is written in a similar vein, and it concentrates on speaking names borne by people, places and things, and provides a discussion of certain ways in which these names can be coined (e.g. anagrams or appropriating names from other semantic fields).

44 per cent of speaking names contain a compound word, and 87.9 per cent of them is a multiword name. The overwhelming majority of toponyms in this category ( 86.3 per cent) is transparent, a small proportion ( 13.5 per cent) contains a partially transparent element, and only 0.4 per cent contains a darkened constituent. 
Table 5: Results of the chi-square $\left(\chi^{2}\right)$ tests of speaking names

\begin{tabular}{|l|l|l|l|l|l|}
\cline { 2 - 6 } \multicolumn{1}{c|}{} & \multicolumn{3}{c|}{ Pearson Chi-square } & \multicolumn{2}{c|}{ Symmetric measures } \\
\cline { 2 - 6 } \multicolumn{1}{c|}{} & value & df & sig & phi & sig \\
\hline Compound & 4.673 & 1 & 0.031 & 0.067 & 0.031 \\
\hline Multiword & 39.196 & 1 & 0.000 & 0.194 & 0.000 \\
\hline Trametic & 208.572 & 1 & 0.000 & -0.447 & 0.000 \\
\hline Semitrans & 606.484 & 1 & 0.000 & 0.763 & 0.000 \\
\hline Darkened & 252.121 & 1 & 0.000 & -0.492 & 0.000 \\
\hline Commonnouns & 184.957 & 1 & 0.000 & -0.421 & 0.000 \\
\hline
\end{tabular}

The comparison of speaking names with the rest of the variables (cf. Table 5 above) shows that this category shows a statistically significant correlation with all the other variables ( $p<0.05$ in each case), however, the $\varphi$ coefficient reveals that only the categories of mimetic names, transparent names, semi-transparent names, darkened names and common noun names display adequate levels of correlational strength.

The highest $\varphi$ value in the case of speaking names is found when they are correlated with common noun names $(\varphi=0.912$, which indicates a very strong positive correlation), which is not surprising at all, given that speaking names must contain synchronically analyzable common nouns in order to be decodable by speakers. Furthermore, strong positive correlation can also be observed between speaking names and transparent names $(\varphi=0.763)$, which means that the other important criterion of speaking names is their semantic transparency. The data seem to confirm our assumption that the game developers coined the speaking names in order to create the appropriate atmosphere for the fictional world of the games. Therefore, it is vital that the players be able to understand the meaning of speaking names, which will evoke the associations they intend to evoke. Similarly, the fact that speaking names show a moderately negative correlation with partially transparent and opaque names $(\varphi=-0.492$ and -0.421 , respectively) confirms this assumption.

According to the results of the Mann-Whitney U-test, speaking names consist of significantly more elements than non-speaking names $(\mathrm{U}=166135, p<$ 0.001). 49 per cent of speaking names consist of one or two elements, while this ratio is 68.6 per cent in the case of non-speaking names. On the contrary, 51 per cent of speaking names comprise more than two elements, but this is only true 
for 31.4 per cent of non-speaking names. These are not unexpected results, because optimally, speaking names can only fully convey their intended meaning content if they explicate it properly. We believe that speaking names contain a higher number of compounds or multiword items because they carry such meanings or extra meanings that cannot be expressed via the already available word-stock of the language, so they need to be combined into neologisms.

\subsection{Transparent names}

We considered those names to be transparent which contain elements that can easily be decoded by the average native English speaker without the need to have prior linguistic knowledge. Since many of the place-names in the ES universe contain elements that are practically extinct in everyday language use or are considered archaic or highly specialized (mostly geographical or religious terms in our case), as a result, their meaning is not accessible to the average present-day speaker. We believe that the reason for the creation of such names is that the developers wanted to make the affected toponyms archaic. Here, the semantic content of the element becomes less important than the relevant associations and the effect it has on the player. Any names that contain specialized vocabulary were put into the 'semi-transparent' category, such as Shinji's Scarp, Sunderstone Gorge, Thaumaturgist's Hut, The Atronach Stone, Toothmaul Gully. Finally, the group of place-names containing darkened or semantically opaque elements also belongs to this larger category. These names are not analyzable for present-day speakers, they do not carry synchronically accessible meanings, or contain lexical items for a fictional language, therefore rendering their meaning inaccessible for speakers of non-fictional languages.

A total of 47.5 per cent of transparent names contain a compound and 86.8 per cent of them comprise at least two separate lexical items. Only 1.3 per cent of the names belonging to this category is mimetic, while 91.1 per cent is a speaking name, and none are semi-transparent or completely obscure. 
Table 6: Results of the chi-square $\left(\chi^{2}\right)$ test of names containing transparent elements

\begin{tabular}{|l|l|l|l|l|l|}
\cline { 2 - 6 } \multicolumn{1}{c|}{} & \multicolumn{3}{c|}{ Pearson Chi-square } & \multicolumn{2}{c|}{ Symmetric measures } \\
\cline { 2 - 7 } \multicolumn{1}{c|}{} & value & df & sig & phi & sig \\
\hline Compound & 19.366 & 1 & 0.031 & 0.136 & 0.000 \\
\hline Multiword & 25.226 & 1 & 0.000 & 0.156 & 0.000 \\
\hline Mimetic & 277.843 & 1 & 0.000 & -0.516 & 0.000 \\
\hline Speakname & 606.484 & 1 & 0.000 & 0.763 & 0.000 \\
\hline Semitrans & 584.905 & 1 & 0.000 & -0.749 & 0.000 \\
\hline Darkened & 173.631 & 1 & 0.000 & -0.408 & 0.000 \\
\hline Commonnouns & 772.907 & 1 & 0.000 & 0.861 & 0.000 \\
\hline
\end{tabular}

The results of the chi-square $\left(\chi^{2}\right)$ tests of transparent names (see Table 6) seem to be in accordance with the results of the categories discussed above. It can be seen that with the exception of compound names and multiword names, all variables show an adequate level of correlational strength, and every variable shows a statistically significant correlation with the category of transparent names ( $p<$ $0.05)$. Unsurprisingly, this category shows the strongest correlation with common noun toponyms $(\varphi=0.861)$, because transparent names have to remain easily analyzable by synchronic speakers. The best way to achieve this is to include a synchronically transparent word in the place-names (e.g. Lost Knife Hideout). It is also logical that this category exhibits a strong negative and a moderately negative correlation with the groups of toponyms containing semi-transparent elements and those containing darkened constituents, respectively $(\varphi=-0.749$ for the semi-transparent group, and $\varphi=-0.408$ for the darkened group), because the categories of transparent and darkened can be seen as each other's opposites. The reason behind these $\varphi$ values is most probably that, in the case of multiword names, darkened and transparent elements can coexist next to each other within the same name, which can distort data and weaken the correlation.

The results of the Mann-Whitney test show that transparent names comprise significantly more elements than do non-transparent ones $(\mathrm{U}=173147, p<$ 0.001). 46.3 per cent of names that contain a transparent element consist of one or two constituents, while the same is true about 70.2 per cent of non-transparent names. Moreover, 53.7 per cent of transparent names are made up of three or more elements, but only 29.7 per cent of non-transparent toponyms have these many constituents. This is due to the fact that the meaning content of non-trans- 
parent names is denser, and fewer linguistic elements are needed to convey its meaning. Our further investigations also confirm this: the Mann-Whitney test revealed that darkened toponyms contain significantly fewer elements than nondarkened ones $(\mathrm{U}=25146, p<0.001)$. Furthermore, 96 per cent of darkened names consist of one or two items, while the same is true about only 52 per cent of non-darkened names.

\subsection{Multiword names}

Those names that did not conform to any of the previously discussed categories were sorted into different groups, which are the groups of multiword names and name containing common nouns. We included names in the latter category if they consist solely of present-day English common nouns. We only put names into this category if they were made up of completely transparent words. If only one of the items was transparent we did not include the name in this category. Each analyzable constituent was counted separately (excluding the definite article the); for instance, Bearclaw Mine was coded as a three-part name, which also contains a compound. The chi-square $\left(\chi^{2}\right)$ test was also run for the common noun toponyms. However, we do not wish to reiterate the results here, as all the relevant pieces of information have already been presented in the previous subsections.

Multiword names differ from compound names in that, in the latter case, the toponyms consist of a compound that is spelled as one word (e.g. Bogmother), while multiword names can include compounds, but they also contain at least one other element that is a separate word altogether (e.g. Firebrand Keep). In the majority of cases, the multiword names contain specifying elements which serve as generic-like constituents that are added for the identifiability of the settlement type (e.g. lake, mill, house, camp, city, cave, manor, mine, watch).

35.4 per cent of multiword names contain a compound and only 19.7 per cent of them is mimetic. 58.6 per cent of names in this group is a speaking name, 54.8 per cent of such names is transparent, 40.7 per cent contains a partially transparent element, while only 4.6 per cent contains an obscured constituent. 63.4 per cent of multiword names comprise a common noun.

In the database, we set up the category of multiword names (as discussed above) and we also treated those names that contain transparent compounds as members of a separate category, distinct from multiword names.

The crosstabs created for the analysis reveal that 69.7 per cent of compound toponyms are multiword name, 59.2 per cent are transparent, 25.4 per cent are semi-transparent, and 15.7 per cent form part of a semantically obscure name. 
58 per cent of compound names are speaking name, 63.1 per cent contain a common noun and 81.9 per cent are not mimetic.

Table 7: Results of the chi-square $\left(\chi^{2}\right)$ test of multiword names

\begin{tabular}{|l|l|l|l|l|l|}
\cline { 2 - 6 } \multicolumn{1}{c|}{} & \multicolumn{2}{l}{ Pearson Chi-square } & \multicolumn{2}{l|}{ Symmetric measures } \\
\cline { 2 - 6 } \multicolumn{1}{c|}{} & value & df & sig & phi & sig \\
\hline Compound & 58.615 & 1 & 0.000 & -0.233 & 0.000 \\
\hline Mimetic & 18.938 & 1 & 0.000 & -0.135 & 0.000 \\
\hline Speakname & 39.196 & 1 & 0.000 & 0.194 & 0.000 \\
\hline Transparent & 25.226 & 1 & 0.000 & 0.156 & 0.000 \\
\hline Semitrans & 56.405 & 1 & 0.000 & 0.233 & 0.000 \\
\hline Darkened & 310.931 & 1 & 0.000 & -0.546 & 0.000 \\
\hline Commonnouns & 46.419 & 1 & 0.000 & 0.211 & 0.000 \\
\hline
\end{tabular}

Table 7 above shows that the category of multiword names shows statistically significant correlations with all the other variables $(p<0.001$ in each case). Yet only in the case of darkened names can we observe an adequate level of correlational strength $(\varphi=-0.546)$. This result is indicative of a moderate negative correlation, meaning that higher values of the darkened name variable correspond to lower values of the multiword variable. The reason for this is that names comprising darkened elements contain fewer constituents, they exhibit less redundancy, are more likely to consist of fewer words than names containing transparent elements. We can observe that the more words a toponym consists of, the more transparent it is, and consequently, carries more meaning.

\section{Conclusions}

In the light of the results returned by the statistical analysis, we can observe two main types of naming in the ES universe: mimetic naming and the creation of speaking names. These two methods are completely distinct from each other in terms of their function and onomastic properties. Mimetic names attempt to create meaning by relying on sounding foreign, at least to English speakers. It is important to note that the speakers' attitude towards the imitated languages (which in this situation can be seen as acting as a quasi-superstrate) can significantly influence the applicability of the mimetic name. By this we are referring to the present-day linguistic prejudices English speakers might have towards other languages and their speakers, especially the ones we identified in the data- 
base. In such cases the need to establish an associative link with the imitated language and all its connotations is very important, and the game developers must have also been aware of such phenomena. The notion of mimetic naming is virtually unknown in the realm of non-fictional onomastics, because it is axiomatic that all names must carry some sort of intended meaning, at least at the moment when they are created.

The other important method of place-name formation in the ES universe is the creation of speaking names, whose relevance and importance is also recognized by non-fictional toponomastics. The reason for this is that speaking names intend to conserve their original meaning for as long as possible: all the speaking names in our database consist of synchronically analyzable common nouns. These speaking names often refer to some geographical feature of the locality or to some important aspect of local life, often in a humorous way.

\subsection{Testing the hypotheses}

H1 Some parallels can be found between the fictional names of the ES series and non-fictional naming, therefore we cannot speak about "postmodern naming" in connection with the toponyms in the games (Tolcsvai Nagy 1996; Slíz 2006)

The fictional names contained in our database are created in accordance with the way in which non-fictional toponyms emerge. On the other hand, the identification of generics and specifics in these fictional names is problematic, because while these names often contain a generic-like element (e.g. Fallowstone Cave, Gloombound Mine, Shivering Isles, Stillrise Village) they are not compounded with the first element of the toponym; hence they do not conform to the compounding pattern exhibited by the vast majority of English place-names (Cameron 1996: 27). In the game, especially in the case of speaking names, the specific elements seem to be the compounds, while the generic-like elements stand alone. Originally we intended to provide a more detailed morphological analysis of these names including the analysis of generics and specific, but this aim was abandoned because of the difficulties pertaining to the analysis of darkened names and because these generic-like elements cannot be construed as analogous with non-fictional generics.

In the database we had 842 toponyms that we classified as multi-word names, which means that 80.8 per cent of the names contained in the database consist of more than one word. In a database of non-fictional place-names, compounded toponyms would be expected to occur in such a ratio. The multi-word names presented in Fekete (2017) drawn from the database of English place- 
names are created exclusively via so-called 'manorial affixes' which denote a new owner or association of the locality. Apart from this difference, fictional name-giving in our database largely follows the conventions and patterns of non-fictional naming.

On the one hand, non-fictional toponyms are originally semantically transparent and can become obscured during the regular historical development of language, for instance, because the words contained in the names fall out of use in the language's lexicon but are preserved as name elements, although without their original semantic content. A phenomenon we observed in the database contradicts this because 114 toponyms (13.8 per cent of the entire database) are created originally as semantically obscure. This would be a very unusual practice in the case of non-fictional place-names.

However, it very often occurs in real toponyms that a name enters the onomasticon of a different language in an already darkened form, which is most frequently the result of historical-demographic factors (e.g. migration, conquest, war, etc.). Although semantic transparency at the time of their emergence is a prerequisite for non-fictional place-names, semantic obscuration does not entail that the speaker will cease to use the name. A similar tendency is also observable in the game: the most frequently occurring obscured place-names tend to belong to long gone civilizations and nations.

At the end of our article, we would like to summarize in what ways our results can be generalized for non-fictional naming. We cannot draw an exact parallel between non-fictional name-giving and the patterns observed in the database, because non-fictional toponyms, as discussed above, are distinct from fictional ones in certain aspects.

The scholarly literature and the results of the statistical analysis have in part confirmed and in part falsified our hypothesis.

H2. Upon preliminary inspection of the games' onomasticon we presuppose that the larger and more significant geographic units exhibit different naming patterns and methods than smaller, less significant ones do.

The data show that the game developers created the names of larger cities and major locations utilizing different methods than they did for the creation of localities that are less relevant to the games' narrative. This distinction proved to be statistically significant.

This hypothesis was in part confirmed by our data analysis.

The Kruskal-Wallis test also showed that in the overwhelming majority of cases the number of elements does not show any significant differences among 
various types of place-names. We found significant differences in only 31 cases, all of which fall into one of two categories: city and major city.

We consider the hypothesis to be partially confirmed because out of the 50 place-name types all the significant differences were found in only two types, which indeed include the names of important locations.

H3. Building on the players' linguistic competence is especially important for name-giving in the games, therefore semantic transparency is of utmost importance in the case of in-game toponyms.

Based on the statistical analysis, it can be observed that altogether 531 names out of 1042 contain a transparent element (51 per cent) and 511 names contain some type of obscured constituent ( 49 per cent). In no way can this be considered a significant difference, thus we reject the hypothesis. However, a closer look at the data sheds more light on the issue, because in the latter category we found 367 partially obscured names (including the previously mentioned toponyms that contain a specialized vocabulary item) and 144 completely obscured ones. In the case of speaking names, transparency is especially prevalent because 86.3 per cent of these names are in fact transparent. The chi-square $\left(\chi^{2}\right)$ tests uncovered a relatively strong positive correlation between the variables of speaking names and transparency $(\varphi=0.763, p<0.001)$. This means that if the value of the speaking name variable is high then the value of the transparent name variable will also be high.

\subsection{Possible directions for future research}

Since basically no scholarly work has hitherto been published about the fictional place-names in video games, we could only begin the investigation into it, as it is far from being complete. Due to reasons of brevity we could not undertake a detailed semantic analysis of the place-names in our database.

One of our original aims was to collect and analyze the individual elements of the toponyms, but due to previously mentioned reasons this did not materialize in the present article. Despite the fact that our database appears to be able to provide generalizable data regarding the examined fictional universe, in order to reach valid, inductive conclusions we would need to include the toponyms of several other game franchises and sandbox-type game series (such as: Baldur's Gate, The Witcher, Fable; Gothic, Fallout, GTA). In accordance with the theory of onymic landscape future research will also have to take into consideration every name in a given fictional universe, not just place-names. 


\section{Notes}

1. Think of, for instance, Dr Henry Jekyll, who is part of our cultural knowledge as much as Abraham Lincoln is.

2. Unless noted otherwise, all direct quotes from non-English sources are translated by the authors of the present article.

3. Due to the restrictions of length, we did not strive for providing a complete account of the history and other aspects of video games, and we did not want to fully present the story of the ES series either. To find out more about the broader research context, we recommend the following works: Beregi (2010), Károlyi (2010), DiPietro (2014), Kuo, Hiler and Lutz (2017), Strong (2018).

4. The lack of the expected high level of elaboration in some aspects of the game world caused an uproar and aroused the gaming community. For example, in 2011, a frequently repeated phrase of Skyrim's non-player character (the city guards) became a meme: "I used to be an adventurer like you, then I took an arrow in the knee" (Kim and mattmanj17, 2011).

5. http://elderscrolls.wikia.com/wiki/The_Elder_Scrolls_Wiki and http://elderscrolls.wikia.com/wiki/Locations (Accessed: 27 June 2018)

6. By this criterion we mean that the name should contain at least one lexical item which is semantically transparent and forms part of the regular lexicon of present-day English. For the sake of simplicity, labels such as 'compound names', 'transparent names', etc. will be used hereinafter to refer to "names that contain at least one compound element" or "at least one transparent element", etc., without having to explicate this for every mention of these categories.

7. The abbreviation for the name of the variables used for corpus analysis in SPSS is given in Table 1.

8. In some cases, however, we could not combine certain categories (e.g. Ayleid ruins and Dwarven ruins, them being related to two important and populous ethnic groups of the games) because they are more significant for the gameplay and for the games' story. On the other hand, we did combine elements pertaining to smaller ethnicities and factions if they were sufficiently similar to each other.

9. This category consists of only one name. 


\section{References}

Adams, Fred, Gary Fuller and Robert Stecker. 1997. The semantics of fictional names. Pacific Philosophical Quarterly 78 (2): 128-148. https://doi.org/ 10.1111/1468-0114.00032.

Barseghyan, Liana. 2017. On some characteristic features of video game discourse. [Foreign Languages at Higher School] 2017 (1): 11-18.

Bell, Alice, Astrid Ensslin and Hans Kristian Rustad (eds.). 2014. Analyzing digital fiction (Routledge Studies in Rhetoric and Stylistics 5). New York: Routledge.

Beregi, Tamás. 2010. Pixelhösök: A számitógépes játékok elsö ötven éve [Pixel Heroes: The first fifty years of video games]. Budapest: Vince.

Bogost, Ian. 2007. Persuasive games: The expressive power of videogames. Cambridge, MA: MIT Press.

Braun, David. 2005. Empty names, fictional names, mythical names. Nous 39 (4): 596-631. https://doi.org/10.1111/j.0029-4624.2005.00541.x.

Bryman, Alan. 2006. Kvantitatív és kvalitatív módszerek összekapcsolása [Linking quantitative and qualitative methods]. In L. Letenyei (ed.). Módszertani kézikönyv résztvevö megfigyelés, fókuszcsoportos interjú, rugalmas kérdöiv, mentális térkép, kapcsolatháló elemzés, interpretációs technikák [Methodological manual participatory observation, focus group interview, flexible questionnaire, mental map, network analysis, interpretation techniques], 371-394. Budapest: Ráció Kiadó.

Butler, James O. 2015. The psychosocial ramifications of videogame naming and representation in the early years of The Simpsons. Names 63 (4): 210219. https://doi.org/10.1179/0027773815Z.000000000123.

Cameron, Kenneth. 1996. English place names. London: B.T. Batsford.

Carney, James D. 1977. Fictional names. Philosophical Studies 32 (4): 383-391.

Carrillo Masso, Isamar. 2009. Developing a methodology for corpus-based computer game studies. Journal of Gaming \& Virtual Worlds 1 (2): 143-169. https://doi.org/10.1386/jgvw.1.2.143/7.

Clark, Cecily. 1992. Onomastics. In R.M. Hogg (ed.). The Cambridge history of the English language. Volume I: The beginnings to 1066, 452-489. Cambridge: Cambridge University Press.

doi:10.1017/CHOL9780521264747.008. 
Csóti, Lili and Boróka Szabó. 2016. A nevek szimbolikája a Harry Potter kötetekben [The symbolism of names in the Harry Potter volumes]. A paper presented at the Munkácsy Tudományos Diákkörök Konferenciája, Kaposvár, Hungary.

Currie, Gregory. 1988. Fictional names. Australasian Journal of Philosophy 66 (4): 471-488. https://doi.org/10.1080/00048408812343531.

Dalen-Oskam, Karina van. 2016. Corpus-based approaches to names in literature. In C. Hough (ed.). The Oxford handbook of names and naming, 344354. Oxford: Oxford University Press. https://doi.org/10.1093/oxfordhb/ 9780199656431.013.40.

Damsa, Andrei and Richárd Fromann. 2016. Gamification and gameful approaches in education, business, and IT. Informatika - A Gábor Dénes Föiskola közleményei [Informatics - Proceedings of the Dénes Gábor College] 18 (1): 28-33.

Debus, Friedhelm. 2002. Namen in literarischen Werken: (Er-)Findung - Form - Funktion (Abhandlungen der Geistes- und Sozialwissenschaftlichen Klasse / Akademie der Wissenschaften und der Literatur 2). Stuttgart: Steiner.

de Ponte, María, Kepa Korta and John Perry. 2018. Truth without reference: The use of fictional names. Topoi. https://doi.org/10.1007/s11245-018-9544-6

DiPietro, Michelle. 2014. Author, text and medievalism in The Elder Scrolls. In D.T. Kline (ed.). Digital gaming re-imagines the Middle Ages, 202-213. New York: Routledge.

Ditrói, Eszter. 2017. Helynévrendszerek modellalapú vizsgálata: A helynévminták összevetö analizise statisztikai megközelítésben [Model-based analysis of place name systems: A comparative analysis of place name patterns in a statistical approach] (A Magyar Névarchívum kiadványai 40). Debrecen: Debreceni Egyetemi Kiadó.

Dörnyei, Zoltán. 2007. Research methods in applied linguistics. Oxford: Oxford University Press.

Ensslin, Astrid (ed.). 2011a. Creating second lives: Community, identity and spatiality as constructions of the virtual (Routledge Studies in New Media and Cyberculture 8). New York: Routledge.

Ensslin, Astrid. 2011b. Do avatars dream of electric steak? Video games and the gendered semiotics of food. Journal of Gaming \& Virtual Worlds 3 (1): $37-$ 50. https://doi.org/10.1386/jgvw.3.1.37_1. 
Ensslin, Astrid. 2011c. The language of gaming. London: Palgrave Macmillan.

Ensslin, Astrid. 2015. Discourse of games. In K. Tracy, T. Sandel and C. Ilie (eds.). The international encyclopedia of language and social interaction. Hoboken, NJ, USA: John Wiley \& Sons. https://doi.org/10.1002/ 9781118611463.wbielsi154.

Fejes, Csilla, Péter Bajor and Richárd Fromann. 2014. Gamification in education - an innovative way to revolutionize logistics tuition. In V.M. Ipavec and T. Kramberger (eds.). 11th International Conference on Logistics and Sustainable Transport. Celje: Faculty of Logistics, University of Maribor.

Fekete, Tamás. 2016. Anglo-Scandinavian code-mixing in English place-names. Studia Anglica Posnaniensia 50 (4): 5-23. https://doi.org/10.1515/stap2015-0018.

Fekete, Tamás. 2017. Historical code-mixing and hybrid place-names in England. PhD dissertation, Pécs: Pécsi Tudományegyetem, Alkalmazott Nyelvészeti Doktori Program. http://nydi.btk.pte.hu/sites/nydi.btk.pte.hu/ files/pdf/FeketeTamas_2017_PhDertekezes.pdf.

Frasca, Gonzalo. 2001. What is ludology? A provisory definition. Ludology.Org (blog), 8 July 2001. http://www.ludology.org/2001/07/what-isludolog.html.

Frasca, Gonzalo. 2003. Simulation versus narrative: Introduction to ludology. In M. J. P. Wolf and B. Perron (eds.). The video game theory reader, 243-258. London \& New York: Routledge.

Frasca, Gonzalo. 2007. Play the message: Play, game and videogame rhetoric. PhD-dissertation. Copenhagen: IT University of Copenhagen.

Fromann, Richárd. 2014. Basics of a gamification based motivational structure. In P. Korondi (ed.). Proceedings of ARES'14: Workshop on Application of Robotics for Enhanced Security, 7-10. Budapest: BUTE.

Fromann, Richárd. 2012. Gamification épülőben a Homo Ludens társadalma? [Gamification - is the society of Homo Ludens in the making?] In E. Nagy (ed.). A fiatal kutatók Magyarország megújulásáért: A Professzorok az Európai Magyarországért Egyesület 3. PhD konferenciája [Young Researchers for the Rejuvenation of Hungary: The 3rd PhD Conference of Professors for the European Hungary], 11-24. Budapest: Professzorok az Európai Magyarországért Egyesület.

Fromann, Richárd. 2017. Játékoslét [Being players]. Budapest: Typotex Kiadó. 
Gammeltoft, Peder. 2007. Scandinavian naming-systems in the Hebrides - a way of understanding how the Scandinavians were in contact with Gaels and Picts? In B.B. Smith and S. Taylor (eds.). West over sea: Studies in Scandinavian sea-borne expansion and settlement before 1300. A festschrift in honour of Dr. Barbara E. Crawford, 479-496. Leiden: Brill.

Goh, Richmond. 2016. Game analysis of The Elder Scrolls V: Skyrim, http:// www.academia.edu/30312246/

Game_Analysis_of_The_Elder_Scrolls_V_Skyrim. Manuscript.

Huizinga, Johan H. 1980. Homo ludens. Boston, USA, and London, UK: Routledge.

Huzsvai, László and Vincze Szilvia. 2012. SPSS Statisztika [SPSS statistics]. Budapest: Seneca Books.

Juhász, Valéria. 2007. Egy internetes honlap, az Iwiw szegedi felhasználóinak szociolingvisztikai vizsgálata, különös tekintettel a nemre és a korra [A sociolinguistic study of a web site, Iwiw in Szeged, Hungary with special regard to gender and age]. PhD dissertation. Pécs: Pécsi Tudományegyetem Nyelvtudományi Doktori Iskola.

Károlyi, Júlia. 2010. Játékok és játékosok [Video games and the players]. Tanitani Online, 13 March 2010. http://www.tani-tani.info/092_karolyi.

Kelley, James B. 2012. Gay naming in online gaming. Names 60 (4): 193-200. https://doi.org/10.1179/0027773812Z.00000000030.

Kepes Júlia. 2009. Egy online számítógépes szerepjáték karakterneveinek névtani vizsgálata [An onomastic analysis of character names in an online role playing computer game]. MA Thesis. Budapest: Eötvös Loránd Tudományegyetem Bölcsészettudományi Kar.

Kim, Brad and mattmanj17. 2011. I took an arrow in the knee. Know Your Meme. http://knowyourmeme.com/memes/i-took-an-arrow-in-the-knee.

Kline, Daniel T. (ed.). 2014. Digital gaming re-imagines the Middle Ages (Routledge Studies in New Media and Cyberculture 15). New York: Routledge.

Kuo, Andrew, Jacob L. Hiler and Richard J. Lutz. 2017. From Super Mario to Skyrim: A framework for the evolution of video game consumption. Journal of Consumer Behaviour 16 (2): 101-120. https://doi.org/10.1002/ cb. 1620 .

Majewski, Jakub. 2017. The Elder Scrolls. In R. Mejia, J. Banks and A. Adams (eds.). 100 greatest video game franchises, 52-54. Lanham, Maryland: Rowman \& Littlefield. 
Makuch, Eddie. 2018. E3 2018: Elder Scrolls 6 Boss knows the game's release date, but he won't tell you. GameSpot (blog), 13 June 2018. https:// www.gamespot.com/articles/e3-2018-elder-scrolls-6-boss-knows-thegames-relea/1100-6459787/.

McGonigal, Jane. 2011. Reality is broken: Why games make us better and how they can change the world. New York: Penguin Press.

Mills, Anthony David. 2011. A dictionary of British place-names (Oxford Paperback Reference). Oxford: Oxford University Press.

Nicolaisen, Wilhelm Fritz Herman. 1976. Place-name legends: An onomastic mythology. Folklore 87 (2): 146-159. https://doi.org/10.1080/0015587X.1976.9716028.

Nilsen, Don L.F. 1982. American proper noun reference: The humorous naming of persons, places, and things. Names 30(3): 171-182. https://oi.org/ 10.1179/nam.1982.30.3.171.

Porkoláb, Ádám. 2017. A magyar blogoszféra netnyelvészeti vizsgálata tartalomtípusok és nemek alapján [An analysis of the Hungarian blogosphere based on gender and content type]. PhD dissertation. Pécs: Pécsi Tudományegyetem, Alkalmazott Nyelvészeti Doktori Program.

Reaney, Percy H. 1985. The origin of English place-names. London: Routledge.

Sajtos, László and Ariel Mitev. 2007. SPSS kutatási és adatelemzési kézikönyv [SPSS research and data analysis manual]. Budapest: Alinea.

Slíz, Mariann. 2006. A beszélő nevek mint a posztmodern eszközei [Speaking names as the tools of postmodernism]. Magyar Nyelvör 2006 (3): 290-301.

Somogyi, Anna. 2015. Az AION online szerepjáték névadási szokásainak és motivációinak nyelvészeti elemzése [A linguistic analysis of name-giving habits and motivations of AION online RPG]. MA Thesis. Veszprém: Pannon Egyetem, Modern Filológiai és Társadalomtudományi Kar, Magyar és Alkalmazott Nyelvtudományi Intézet.

Strong, Samuel. 2018. Gamer-generated language and the localisation of massively multiplayer online role-playing games. $\mathrm{PhD}$ dissertation. London: University College London Centre for Translation Studies.

Székhelyi, Mária and Barna Ildikó. 2003. Túlélőkészlet az SPSS-hez: többváltozós elemzési technikákról társadalomkutatók számára [Survival kit for SPSS: Multivariate analysis techniques for social researchers]. Budapest: Typotex. 
Tiedke, Heidi. 2011. Proper names and their fictional uses. Australasian Journal of Philosophy 89 (4): 707-726. https://doi.org/10.1080/00048402.2010.514930.

Tolcsvai Nagy, Gábor. 1996. A tulajdonnév jelenéstanáról egy névcsoport alapján [On the semantics of the proper name based on a group of names]. Magyar Nyelvör 1996 (3): 319-325. 